\title{
Relationship between Tropical Forest Distribution and Soils on Different Types of Mother Rocks in the Republic of Congo
}

\author{
Koubouana Félix ${ }^{1}$, Atsoumpari Ngakabi Létycia Adeline ${ }^{1}$, Ndzai Saint Fédriche, \\ Ifo Suspense Averti ${ }^{2}$
}

${ }^{1}$ Laboratoire de Géomatique et d'Ecologie Tropicale Appliquée (LGETA), ENSAF, Brazzaville, Congo

${ }^{2}$ Laboratoire de Géomatique et d'Ecologie Tropicale Appliquée (LGETA), ENS, Brazzaville, Congo

Email: averti.ifosuspens@umng.cg

How to cite this paper: Félix, K., Adeline, A. N. L., Fédriche, N. S., \& Averti, I. S. (2019). Relationship between Tropical Forest Distribution and Soils on Different Types of Mother Rocks in the Republic of Congo. Open Journal of Forestry, 9, 341-354. https://doi.org/10.4236/ojf.2019.94019

Received: August 5, 2019

Accepted: October 8, 2019

Published: October 11, 2019

Copyright $\odot 2019$ by author(s) and Scientific Research Publishing Inc. This work is licensed under the Creative Commons Attribution International License (CC BY 4.0).

http://creativecommons.org/licenses/by/4.0/

(c) (i) Open Access

\begin{abstract}
The factors influencing the distribution of forests and their development are important in order to better understand the bio-functioning of tropicals ecosystems forests. The Republic of the Congo has an important forest area of 23.5 million ha subdivided into three large massifs with different forest units from the north until the south of the country. The present study proposes to highlight the relationship between the edaphic and pedological factors and the distribution of the floristic species of some tropical forests of the Congo. To achieve this aim, a principal component analysis (PCA) was to identify similarities or oppositions between variables and to locate the most correlated variables. Also, the indices of biodiversities were used to assess the biodiversity between forest plot and forest sites. A total of 238 species distributed in 46 families were counted. We noted a CS similarity between Mbomo-Kellé and FMU Mokabi-Dzanga of 50\%. However, there was considerable variability between the forests of the Impfondo-Dongou axis and of the forest of other localities. The main component analysis carried out showed that the distribution of floristic species in the studied forests is determined by the edaphic factors.
\end{abstract}

\section{Keywords}

Tropical Forest, Congo, Biodiversity's Indices, Principal Component Analysis, Environmental Factors, Similarity Coefficient

\section{Introduction}

Sustainable management and conservation of forest natural resources have been 
at the forefront of the international community since IPCC reports confirmed the major role the forests could play to mitigate the causes of climate change.

Lewis et al. (2009) showed that African forests were uptake large amounts of excess $\mathrm{CO}_{2}$ from the atmosphere. Tropical forests are at the heart of international negotiations and are the subject of several studies to better understand the role they play in sustainable development, climate change and maintaining the global balance (Phillips et al., 2009).

This interest of the international community is justified by the fact that they occupy about $7 \%$ of the terrestrial surfaces (OFAC, 2007), shelter more than half of the planet's biological diversity (Gardner et al., 2010; Wilson, 1988) or more than 10,000 species of plants, of which about 3000 are endemic (OFAC, 2007), and sequester around 547.8 million tonnes of carbon (UN-REDD, 2015).

Among these forests, we have the forests of the Republic of Congo with an area of 23.5 million ha or $69 \%$ of the national territory (NERF, 2016; CNIAF/MEFDD, 2015). The Congolese forest area is present in three large massifs: Mayombe (1,503,172 ha), Chaillu (4,386,633 ha) and massif du Nord-Congo (15991.604 ha) which is by far the largest in area (NERF, 2016). These forest massifs are subdivided into the Forestry Development Unit (FMU) and the Forestry Operations Unit (FEU), which are now the subject of several floristic studies.

Climate, edaphic and floristic heterogeneity makes it difficult to make any attempt to link a justified soil type with type of vegetation. Indeed, several factors make this relationship difficult: great soil leaching in the intertropical zone, differences in the duration of the rainy season or the dry season; anthropogenic activities (logging, agricultural activities) alter the physico chemical compositions of soils and have an impact on the floristic composition of forests.

Several studies have been done in recent years in Congolese forests (Koubouana et al., 2015; Ifo et al., 2016), and improved the knowledge of these forests in terms of floristic biodiversity, carbon stock in the various reservoirs (Ifo et al., 2016).

These different studies conducted in these forests not only showed some local differences, but also revealed a regional north-south and east-west floristic gradient (Kimpouni, Apani, \& Motom, 2013). In the northern part of Congo, we can mention: Moutsamboté (2012) on the ecological, phytogeographic and phytosociological study of northern Congo, Nkokolo (2013) in FMU Mokabi-Dzanga, Mondzali-Lenguiya (2015) on floristic and structural analysis FMU Mbomo-Kellé in northwestern Congo.

Existing studies in the south of the country on the vegetation of FMU Letili and Bambama, Koubouana et al. (2015) on the biodiversity structure and flora of trees in the secondary rainforest in southwestern Congo, as well as the work of Mbété et al. (2019) on the woody potential of the FEU Mpoukou-Ogooué in the Chaillu massif. Although these studies have shown differences in floristic scans between botanical surveys of different sites, none of them make the actual link 
between flora and mother rock, or pedological factors.

Yet, the distribution of tropical forests on a global scale, within continents and countries, was not randomly. Some authors claim that if, at the biogeographic scale, forest communities are linked to geological, historical and climatic causes (Ricklefs, 2006; Gaston, 2000), the factors like the relief, the substrate and the abiotic conditions are most likely to explain the coexistence of species on a regional or local scale (Condit et al., 2012). At the global level, some studies have been conducted to see the links between vegetation and soils on different types of parent rocks (Verheye, 1972; Laura di Feo, 2011; Sayre, 2014). These studies showed that in many cases there was a strong link between the different types of vegetation cover and the soil type following the source rock. Boudy, (1948) stated "The forest soil is of little importance and that because of the action of the roots is the the rock or less altered, mother rock, the geological soil in one word, that plays the main role from the edaphic point of view, fires, runoff most often destroyed the forest floor.".

However, it is important to note that this relationship is not always obvious to elucidate.

In the Republic of Congo, despite these efforts to know the floristic composition of different forests, it is fitting to indicate that very few comparison studies between the forest ecosystems of the North and those of the South have been carried out in Congo. On both sides, there are no in-depth studies to understand what are the different factors that explain the distributions forest throughout the entire national territory.

It is with this in mind that the overall objective of this study is to highlight the impact of edaphic and geological factors on the distribution of floristic species between four localities located in North Congo (Mokabi-Dzanga, area Impfondo-Doungou), central-western Congo (Mbomo-Kellé) and southwestern Congo (Gouongo), with a view to improve knowledge of the parameters that ensure the functioning of Congo's forest ecosystems. Specifically; It aims to: 1) study the distribution of floristic species in the study areas; 2) highlight the determinants of this distribution of floristic species.

\section{Material and Methods}

\subsection{Introducing Study Areas}

The floristic data from this study were obtained from four sites with different environmental characteristics. There are: FMU Mokabi-Dzanga, Mbomo Kellés FMU, Gouongo's FEU and forests on the Impfondo-Dongou axis (Figure 1). We have chosen randomly four sites based on the characteristic of flora. The 4 sites have different environmental characteristics (climate, geological substrate, soils, etc.). One site to the south (GOUONGO, one site in the north-south, MOKABIDZANGA in the far north and another in IMPFONDO-DONGOU in the north east. Mbomo-Kelle is a transition zone in terms of forest flora between southern Congo and northern Congo. 


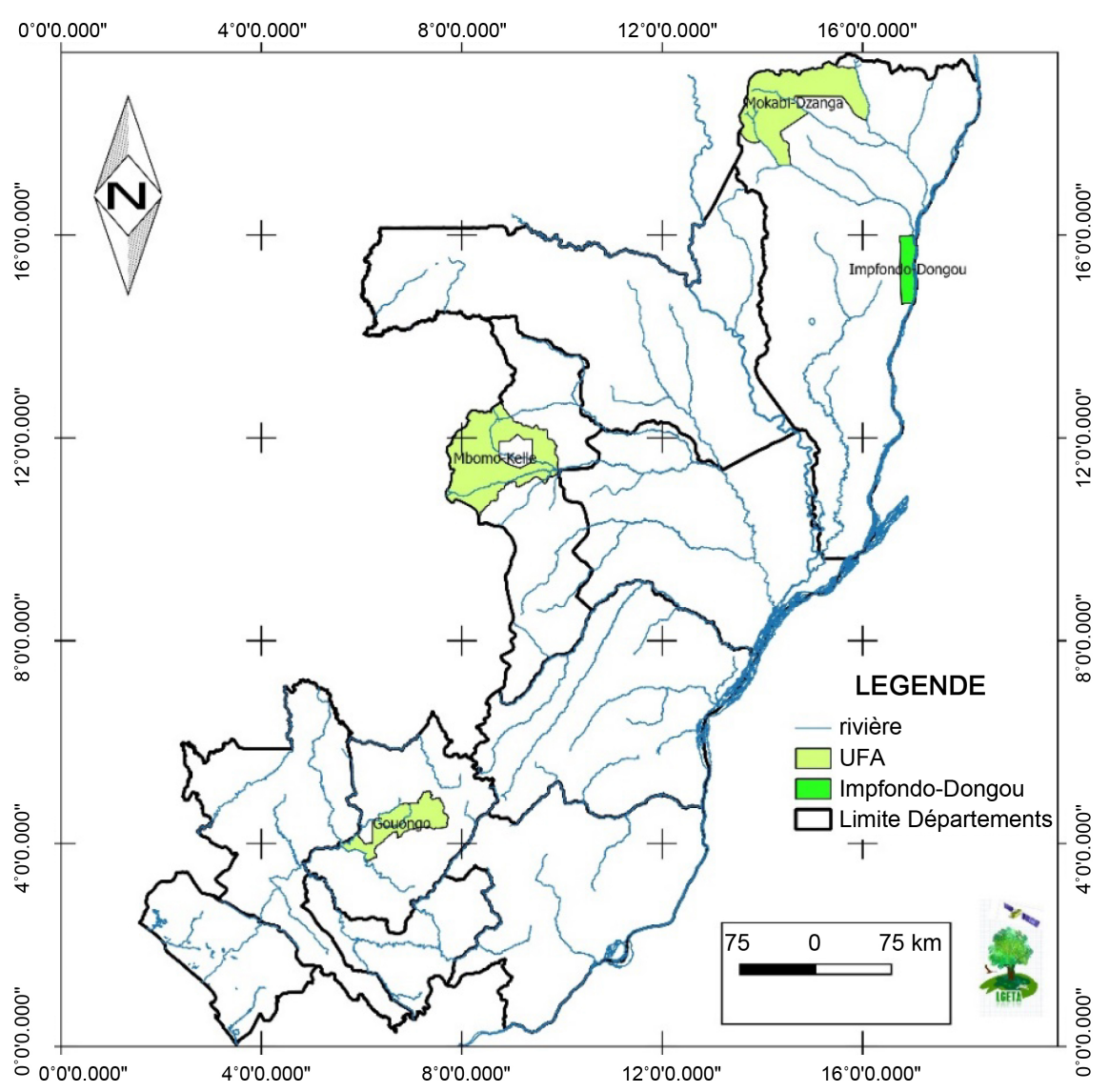

Figure 1. Study area.

\subsection{Methods for Collecting Field Data}

Data from management inventories were collected along the $2 \mathrm{~km}$ equidistant layout previously opened in the 3 logging forest concessions (Mokabi-Dzanga, Mbomo-Kellé and Gouongo). In the adjoining plots of $25 \mathrm{~m} \times 200 \mathrm{~m}$ or 0.5 ha delineated stretches, all plant species of Diameters at Breast Height (DBH) $\geq 20$ $\mathrm{cm}$ (Figure 2) were noted. In total, 09 ha of inventory data were collected into the 3 forest concessions.

With regard to the botanical inventory in the forests of the Impfondo-Dongou axis, plots of $50 \mathrm{~m} \times 50 \mathrm{~m}$ have been delimited between Impfondo and Dongou. To allow for a better inventory, these plots were then subdivided into $25 \mathrm{~m} \times 25$ $\mathrm{m}$ plots in which all species of DHP-20 cm were identified (Figure 3). DBHs and the number of tree individuals were noted. For trees with buttresses or stilt roots, $\mathrm{DBH}$ was measured at $30 \mathrm{~cm}$ above them.

\subsection{Data Processing Methods}

\subsubsection{Preparing the Database}

All inventory data have been compiled using the Microsoft Excel spreadsheet, and the scientific names have been updated according to the classification system of Angiospermy Phyllogeny Group (APG IV). This database allowed us to do all possible analyses to arrive at the expected results of the study. The data 


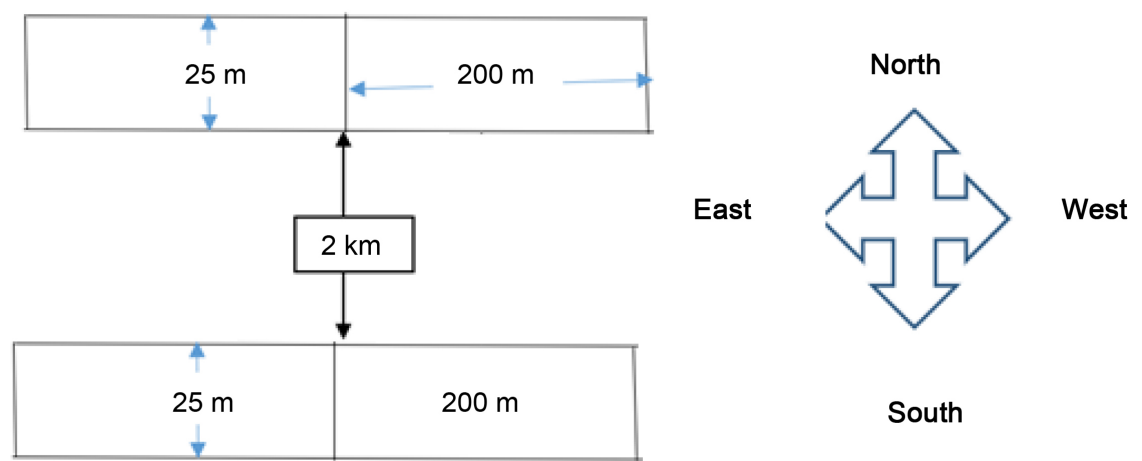

Figure 2. Experimental plot design in the forest concession.

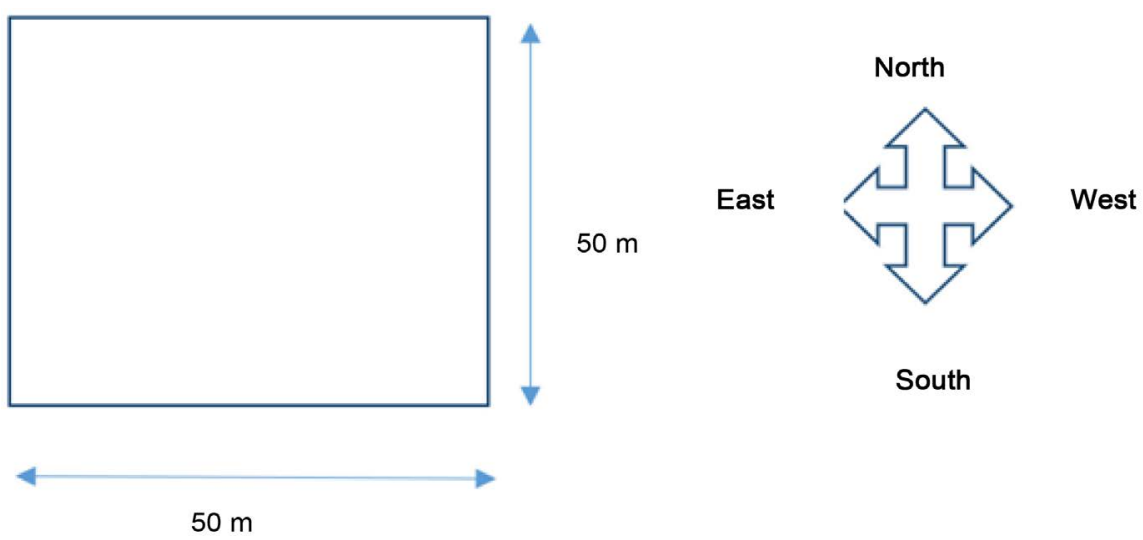

Figure 3. Experimental plot design in the forest of Impfondo-Dongou.

processing took place in two phases, including:

\section{- Development of lists in absence}

From the elaborate database, a table describing the presence or absence of species in the 4 localities was extracted and another detailing the abundance of each species in the floristic surveys carried out in order to carry out an analysis in Component Principle. For better handling, a specific coding was applied. As a result, the codes assigned to localities are: R1-FMU Mbomo Kellé, R2-Impfondo Dongou Zone, R3-FMU Mokabi-Dzanga, R4-FEU Gouongo.

\section{- Analysis in key components}

Main Component Analysis (CPAs) is part of the multidimensional descriptive methods group called factor methods. It is used to highlight similarities or contrasts between variables and to identify the variables most correlated with each other. CPA consists of replacing a family of variables with new variables of maximum variance, not correlated two to two, which are linear combinations of the original variables. These new variables, called main components, define factor planes that form the basis for a flat graphic representation of the initial variables. Interpretation of the results is generally limited to the first two factor planes, provided that they account for most of the variance in the cloud of the initial variables. In this study, the PCA identifies the similarity between or the contrasts between floristic surveys from a floristic composition allot. This simi- 
larity or opposition is explained by the environmental variables of each floristic survey. This analysis is based on pre-established software. In the case of this study, the main component analysis was conducted using CANOCO 4.5 software.

\subsubsection{Methods for Assessing Biodiversity}

In order to determine the floristic composition of this study, several parameters and indices of floristic diversity will be used, including: Specific wealth; The goal and weighted spectra;

\section{- Shannon Index}

The Shannon Index expresses diversity by taking into account the number of species and the abundance of individuals within each of these species. Thus, a community dominated by a single species will have a lower coefficient than a community with all species co-dominant. It is represented by a real positive number often between 0 and 5 . The Shannon Index $\left(H^{\prime}\right)$ is calculated using the following equation:

$$
H^{\prime}=-\sum_{i=1}^{n}\left(p_{i} \log _{2} p_{i}\right)
$$

where $H^{\prime}$ is the Shannon index, $p_{i}-n i / \mathrm{N}$ is the probability of counting species $i$, nor the number of individuals of species $i$ and $\mathrm{N}$ the total number of individuals.

\section{- Equitability or Pielou Index}

The equitability index is the Shannon Maximum Diversity Index report. It marks the level of diversity achieved by the system relative to the maximum possible (Ifo et al., 2016).

$$
\begin{gathered}
J=\frac{H^{\prime}}{H^{\prime} \max } \\
H^{\prime} \max =\log _{2} S
\end{gathered}
$$

$J$ is the Pielou index, $H^{\prime}$ is the Shannon index and $H^{\prime} \max$ is the logarithm of the total number of species $(S)$. The values of the Piélou index are between 0 and 1 . When they tend to 0 , a dominance phenomenon is revealed and when they tend to 1, the index marks a regular compensation of individuals among species (Ifo et al., 2016).

\subsection{Similarity Indices}

This category of indices is intended to compare objects on the basis of presence-absence of species. To calculate the similarity coefficients of our samples, we used two binary coefficients excluding double zeros; this is the Jaccard coefficient $(S)$ and the coefficient of Surensen $(K)$. The best known is the Jaccard coefficient. The coefficient of Sarensen gives a weight twice as high to the double presence, one can consider the presence of a species more informative than its absence. We used similarity indices in our study to verify and confirm the results of the main component analysis 


$$
\begin{gathered}
S(\%)=\frac{a}{b+c-a} \times 100 \\
K(\%)=\frac{2 a}{b+c} \times 100
\end{gathered}
$$

a-Number of common attendances for both samples (X1 and X2);

$b$-Number of presence specific to the X2 sample;

$c$-Number of presence specific to the X1 sample.

\section{Results}

\subsection{Floristic Diversity}

The floristic survey carried out in the various localities: FMU Mbomo-Kellé, FMU Mokabi-Dzanga, FEU Gouongo and the Impfondo-Doungou axis allowed the count of DHP trees- $20 \mathrm{~cm}$, divided into 238 species in 45 families.

In the entire floristic inventory carried out, it appears that the FabaceaeCaesalpinioideae (31 species) are the most represented followed by FabaceaeMimoisoideae (18 species), Rubiaceae (18 species), Euphorbiaceae (17 species), Meliaceae (12 species), as well as Annonaceae (11 species) and Malvaceae-Tiliacoideae (11 species).

The calculation of Shannon and Weaver's indices and equitability allowed us to appreciate the diversity of flora in each locality by considering the number of individuals per species and the total number of individuals in each locality. The results show that the Shannon index varies between 3.73 and 4.21 bits and the equitability between 0.77 and 0.84 , indicating a high diversity of flora and an equitable distribution of individuals within the species studied.

With regard to the floristic affinities between the surveys, it appears that the values of the Jaccard index vary between 14.93 and 45.26 percent and those of Sorensen between 25.97 and 62.32 per cent. The similarity of the statements is only confirmed when the value of the Sorensen index is greater than $50 \%$. Thus, there is a great similarity between FMU Mbomo-Kellé (R1) and FEU Gouongo (R4) because the coefficient values are above $60 \%$. There is also a similarity between Mbomo-Kellé (R1) and FMU Mokabi Dzanga (R3) with values above $50 \%$. However, there is a great variability between the Impfondo-Doungou axis and other localities with values below $35 \%$.

\subsection{Floristic Distribution in Surveys}

\subsubsection{PCA Results on Attendance-Absence}

The main plan for PCA based on a species absence table in each locality explains more than $77 \%$ of the species distribution in the surveys conducted Indeed, Figure 4 shows the layout of the surveys in the main plane with all around the species characteristic of each survey.

We also note that, considering axis 1, the surveys are arranged in two groups:

The Impfondo-Dongou and Mokabi-Dzanga (R2-R3) zones are on the positive side of axis 1 ; 


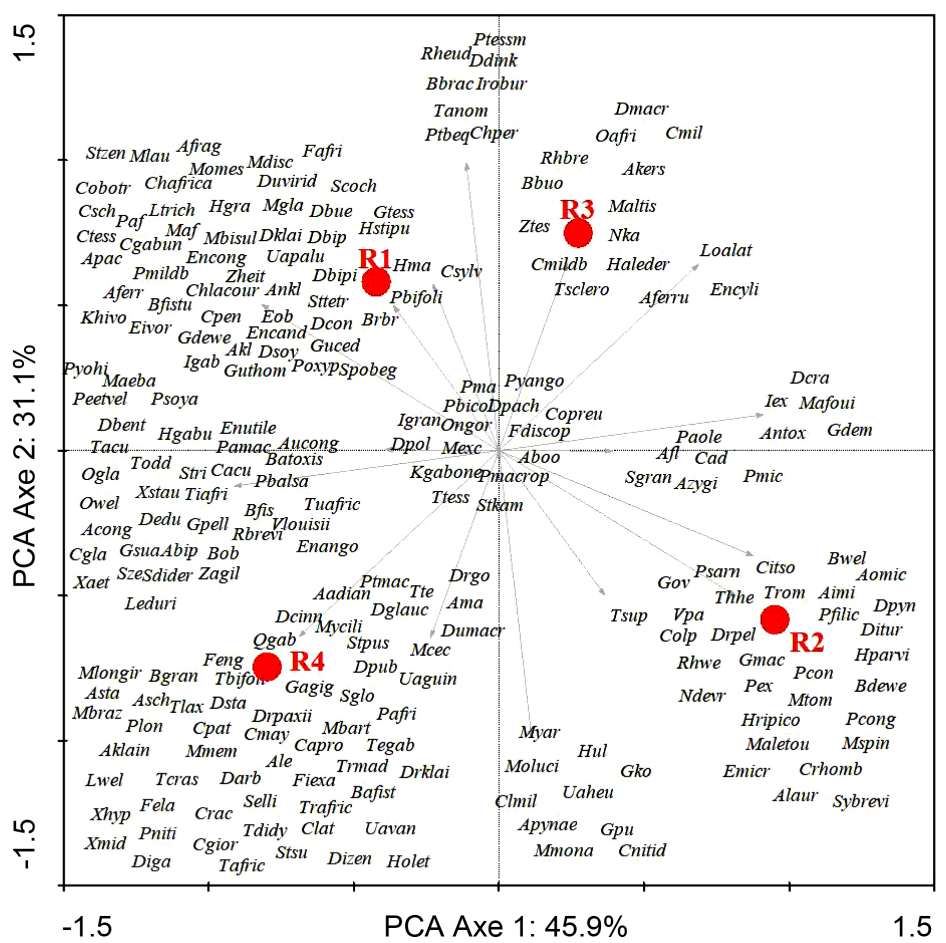

Figure 4. CPA results in presence-absence.

Mbomo-Kellé and Gouongo (R1 and R4) are on the negative side of axis 1.

This provision of surveys on axis 1 confirms the results obtained by the similarity indices. By linking the arrangement of these surveys on this axis 1 with edaphic and soil factors, it appears that the R1 and R4 surveys were carried out on the lower precambrian geological substrate with a metamorphic complex and granites, while the R2 and R3 surveys on alluvial formations for Impfondo-Dongou and carnot sandstones for the Mokabi-Dzanga Forest (Table 1). Axis 1 therefore discriminates against our surveys according to the composition of the geological substrate.

Similarly, considering axis 2, there are two distinct groups:

- Mbomo-Kellé and Mokabi-Ndzanga (R1-R3) are on the positive side of axis 2 ;

- The Impfondo-Doungou and Gouongo (R2-R4) zone are on the negative de axis 2.

The floristic surveys of the Mbomo-Kellé and Mokabi-Dzanga groups were carried out on exonerated soils, while those of the Impfondo-Dongou and Gouongo groups were carried out on flooded and flooded soils. Axis 2 discriminates against surveys based on the degree of hydromorphia.

\subsubsection{PCA Results from Tree Numbers per Survey}

The PCA's results from the abundance table discriminate against our surveys on axis 1 in two groups: the Impfondo-Doungou zone (R2) is on the positive side of axis 1 while Mbomo-kellé, Mokabi-Dzanga and Gouongo (R1, R3 and R4) are from the negative side of axis 1 . Similarly, considering axis 2, there are two 
Table 1. Edaphic characteristics and vegetation types of the study areas.

\begin{tabular}{|c|c|c|c|c|}
\hline Study area & Rain fall & Types of soils & Vegetation & $\begin{array}{l}\text { Geographic } \\
\text { coordinates }\end{array}$ \\
\hline $\begin{array}{l}\text { MBOMO-KELLE } \\
\text { logging concessions }\end{array}$ & $\begin{array}{c}1450-2100 \\
\mathrm{~mm}\end{array}$ & $\begin{array}{l}\text { Ferrallic soils } \\
\text { Hydromorphic } \\
\text { soils }\end{array}$ & $\begin{array}{l}\text { Forests on terra } \\
\text { firma } \\
\text { Swamp forests }\end{array}$ & $\begin{array}{l}14^{\circ} 00^{\prime \prime} \mathrm{E} \text {; } \\
15^{\circ} 00^{\prime \prime} \mathrm{E} \text {; and } \\
00^{\circ} 27^{\prime} 35.9^{\prime \prime} \\
\text { North } \\
00^{\circ} 22^{\prime} 03^{\prime \prime} \\
\text { South }\end{array}$ \\
\hline $\begin{array}{c}\text { MOKABI-DZANG } \\
\text { A logging } \\
\text { concessions }\end{array}$ & $\begin{array}{c}1500-2000 \\
\mathrm{~mm}\end{array}$ & $\begin{array}{l}\text { Ferrallic soils } \\
\text { Hydromorphic } \\
\text { soils }\end{array}$ & $\begin{array}{l}\text { Meliaceae forest } \\
\text { on terra firma } \\
\text { Some forests on } \\
\text { terra firma }\end{array}$ & $\begin{array}{l}\text { Latitudes } 2^{\circ} 40^{\prime} \\
\text { et } 3^{\circ} 40^{\prime} \text { Nord } \\
\text { et les } \\
\text { longitudes } \\
16^{\circ} 30^{\prime} \text { et } \\
17^{\circ} 40^{\prime} \text { Est }\end{array}$ \\
\hline $\begin{array}{c}\text { GOUONGO } \\
\text { logging concessions }\end{array}$ & $\begin{array}{c}1400-1600 \\
\mathrm{~mm}\end{array}$ & $\begin{array}{l}\text { Soils on granites } \\
\text { and exoned } \\
\text { Gneiss } \\
\text { Hydromorphic } \\
\text { soils }\end{array}$ & $\begin{array}{l}\text { Forests on terra } \\
\text { firma } \\
\text { Forest on } \\
\text { Hydromorphic } \\
\text { soil }\end{array}$ & $\begin{array}{l}03^{\circ} 07^{\prime} 22.9 \text { Sud; } \\
13^{\circ} 15^{\prime} 00.0 \text { Est }\end{array}$ \\
\hline $\begin{array}{l}\text { IMPFONDO-DON } \\
\text { GOU forest }\end{array}$ & $\begin{array}{c}1600-1800 \\
\mathrm{~mm}\end{array}$ & $\begin{array}{l}\text { Ferrallic soils } \\
\text { Hydromorphic } \\
\text { soils }\end{array}$ & $\begin{array}{l}\text { Forests on terra } \\
\text { firma } \\
\text { Swamp forests } \\
\text { Degraded forest }\end{array}$ & $\begin{array}{l}\text { Lat, } \\
2^{\circ} 2^{\prime} 47.56^{\prime \prime N} ; \\
\text { Long, } \\
18^{\circ} 3^{\prime} 3.51^{\prime \prime E}\end{array}$ \\
\hline
\end{tabular}

groups of surveys, group 1 consisting of Mokabi-Dzanga (R3) opposes Group 2 consisting of Mbomo-Kellé, Impfondo-Dongou Zone and Gouongo (R1, R2 and R4) As shown in Figure 5.

This distribution could probably have an explanation in the finer analysis of edaphic and pedological factors. Our macroscopic observations did not allow us to give a plausible explanation of the distribution of surveys on axis 2 .

\section{Discussion}

\subsection{Floristic Wealth}

Analysis of the floristic composition of the various floristic surveys has showed that Fabaceae in general are the most represented and Fabaceae-Caesalpinioideae in the particular constitute the most abundant family of these ecosystems Forest. This dominance is simply due because the Fabaceae are the most important family of leguminous plants that include Fabaceae-Caesalpinioideae, Fabaceae-Mimosoideae and Fabaceae-Faboideae. These observations support the affirmation that the tropical rainforests are specifically rich with a large representation of legumes (Pascal, 2003).

In addition, several studies carried out in the Congo basin have shown the abundance of Fabaceae. Moutsamboté, (2012), finds the Fabaceae or Leguminosae as the most represented family. Doucet (2003) found a high density of Fabaceae in the forests of central of Gabon. This abundance has also been demonstrated in congolese forests (Kimpouni et al., 2008; Koubouana et al., 2015, 


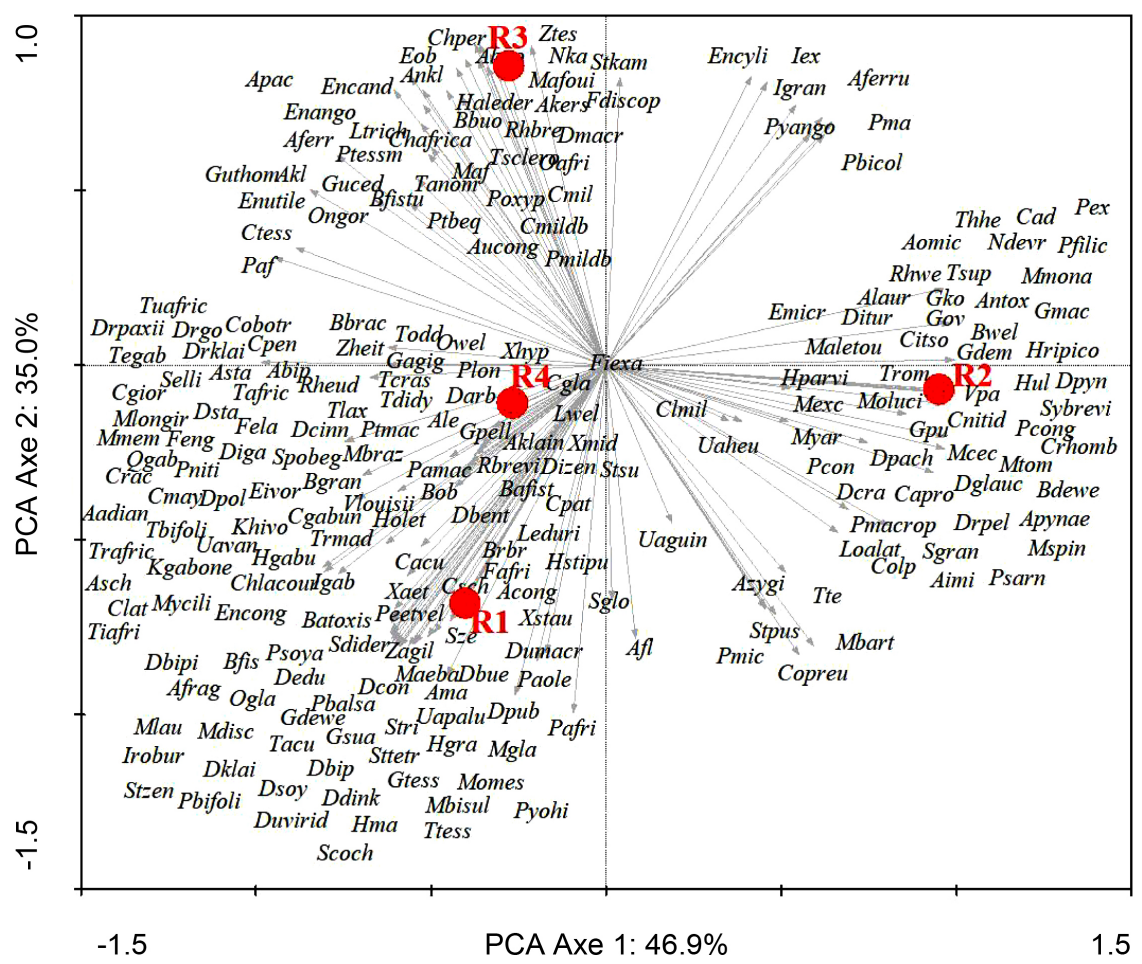

Figure 5. CPA results from the survey tree count.

2016; Miabangana \& Lubini Ayingweu, 2015) on the floristic and phytogeographic analysis of the vegetation of Loufézou Island in Brazzaville confirms the same dominance of the Fabaceae family.

\subsection{Diversity and Heterogeneity in the Forests Studied}

The Shannon-Weaver index values calculated in the forests studied are around 4 bits, showing a great diversity without dominance of one species or group of species over the others and an equitable distribution of species in the different botanical families met. Several authors have used this index to characterize the floristic diversity of the ecosystems studied. Shannon-Weaver index values obtained in our forests are close to those calculated by Koualalanda (2019) in the primary forests of the Tékés Plateaux, Koubouana et al. (2016) in the forests of Northern Congo, Omatoko et al. (2015) in the UMA plain forest in the Democratic Republic of Congo and Abdourhamane et al. (2013) in the Dankada and Dodo-Dan Gado classified forest complex in Niger. On the other hand, they are lower than those obtained by Agbani et al. (2018) in the plant formations of the sacred forest of Nassou in the Sudanese area of Benin, with Shannon index values exceeding 5 bits. It should be noted that the lowest values in the Shannon-Weaver index are noted in degraded forests; this is the case of the degraded forests of the Tékés Plateaus (Koualalanda, 2019) and the Brazzaville Goose's Foot Forest (Kimpouni, Mbou, Gakosso, \& Motom, 2013).

In addition, the values of the Sorensen similarity coefficient showed a florist affinity between the floristic surveys of FEU Gouongo and FMU Mbomo-Kellé 
(62.32\%) FMU Mbomo-Kellé and Mokabi-Dzanga (51.49\%). The high value of the Sorensen similarity coefficient between FEU Gouongo and FMU Mbomo-Kellé shows the transition character between the forests of the Southwest and the forests of northwestern Congo.

These results on the PCA showed that there is a floristic affinity between the Mbomo-Kellé and Mokabi-Dzanga groups because these floristic surveys were carried out on exonerated soils, while those of the Impfondo-Dongou and Gouongo groups were carried out on flooded soils flood-flooded. This proves that ecology plays a key role in the distribution of plant species on a given.

These PCA have also shown that the distribution of species in the various forest ecosystems studied is determined by edaphic factors, including the geological substrate. This action of the substrate is reinforced locally by climatic factors including rainfall. This result is in line with that of Koubouana (2010) obtained in the Niari Valley. In addition, the role of edaphic factors as determinants of tree distribution is well documented in tropical forest (Webb \& Peart, 2000; Itoh et al., 2003).

However, we find that our PCA results on the basis of tree numbers appear independent of the edaphic and climatic variables studied in considering axis 2 of this main plan. This study may not have incorporated some critical factors. Indeed, the chemical composition of soils would have influenced not only the number of individuals per species but also their presence or absence. Numerous research in tropical forests in Africa and the Amazon has shown links between soil nutrient levels and the presence of certain tree species (Svenning et al., 2004; Mirkka et al., 2005).

\section{Conclusion}

The study on the relationship between forest vegetation and soils on different types of geological substrates in the forest ecosystems of the Republic of Congo allowed us to understand the distribution of forest species in different areas. The most abundant families are Fabaceae-Caesalpinioideae, Fabaceae-Mimosoideae, Burseraceae, Sapotaceae and Myristicaceae. The values of the Shannon-Weaver index showed that the forest ecosystems studied have a high diversity of flora with lack of dominance of one species or group of species over other species. The values of the Sorensen index showed a florist affinity between the floristic surveys of FEU Gouongo and FMU Mbomo-Kellé as well as between those of FMU Mbomo-Kellé and Mokabi-Dzanga. The main component analyses carried out not only confirmed these floristic affinities, but also discriminated in two groups of forests: forests on metamorphic rocks and granites (FEU Gouongo and FMU Mbomo-Kellé) and forests on Grés de Carnot (forests of FMU Mokabi-Dzanga) as well as forests on alluvial formations (forests of the Impfondo-Dongou axis). As a result, it can be concluded that the distribution of floristic species in the forest ecosystems studied is under the control of rock mother factors. Climate factors, including the duration of rainfall per year in an area, 
reinforce the action of edaphic factors by weighing tree numbers. This action of climatic factors deserves a specific study to elucidate it. Similarly, the contribution of fine soil data may be a future area of research to better clarify the action of edaphic factors on the spatial distribution of species in forests.

\section{Acknowledgements}

We express our deep gratitude to Dr. Ibala Zamba Armel for her valuable support in the statistical processing of our field data. Our thanks also go to the forest concession managers of Mbomo-Kellé, Mokabi-Dzanga and Gouongo for their assistance in collecting data on the ground.

\section{Conflicts of Interest}

The authors declare no conflicts of interest regarding the publication of this paper.

\section{References}

Abdourhamane, H., Morou, B., Rabiou, H., \& Mahamane, A. (2013). Floristic Characteristics, Diversity and Structure of Woody Vegetation in South-Central Niger: Case of the Dan Kada Dodo-Dan Gado Classified Forest Complex (21 p.). Maradi: Maradi of University.

Agbani, P. O., Amagnide, A., Goussanou, C., Azihou, F., \& Sinsin, B. (2018). Structure of Woody Stands of Plant Formations of the Sacred Forest of Nassou in the Sudan Area of Benin. International Journal of Biological and Chemical Sciences, 12, 2519-2534. https://doi.org/10.4314/ijbcs.v12i6.5

Boudy, P. (1948). Economie forestière nord-africaine: Description forestière de l'Algérie et Tunisie (Vol. 1, 22 p.).

CNIAF/MEFDD (2015). Results of Calculations to Determine Biomass, Carbon and Emission Factors of the National Forest Inventory (NI) in the Republic of Congo Brazzaville (40 p.).

Condit, R., Chisholm, R. A., \& Hubbell, S. P. (2012). Thirty Years of Forest Census at Barro Colorado and the Importance of Immigration in Maintaining Diversity. PLoS ONE, 7, e49826. https://doi.org/10.1371/journal.pone.0049826

Doucet, J. L. (2003). L'alliance délicate de la gestion forestière et de la biodiversité dans les forêts du Centre du Gabon (323 p). Thèse de Doctorat, Gembloux: Faculté Universitaire des Sciences Agronomiques de Gembloux.

Gardner, T. A., Barlow, J., Sodhi, N. S., \& Peres, C. A. (2010). A Multi-Region Assessment of Tropical Forest Biodiversity in a Human-Modified World. Biological Conservation, 143, 2293-2300. https://doi.org/10.1016/j.biocon.2010.05.017

Gaston, K. J. (2000). Biodiversity: Higher Taxon Richness. Departement of Animal and Plan Sciences (Vol. 24, pp. 117-127). Sheffield: University of Sheffield.

https://doi.org/10.1191/030913300673943469

Ifo, S. A., Moutsamboté, J.-M., Koubouana, F., Yoka, J., Ndzai, S.-F., Bouetou-Kadilamio, O. N. L., Mampouya, H., Jourdain, C., Bocko, Y., Mantota, B. A., Mbemba, M., Mouanga-Sakhat, D., Odendé, R., Mondzali-Lenguiya, R., Mampouya Wenina, Y. E., Ouissika, C. B., \& Loumeto, J. J. (2016). Tree Species Diversity, Richness, and Similarity in Intact and Degraded Forest in the Tropical Rainforest of the Congo Basin: Case of the Forest of Likouala in the Republic of Congo. International Journal of Forestry Re- 
search, 2016, Article ID: 7593681. https://doi.org/10.1155/2016/7593681

Itoh, M., Kim, C., Palardy, G., Oda, T., Jiang, Y. J., Maust, D., Yeo, S. Y., Lorick, K., Wrigt, G. J., Ariza-McNaughton, L., Weissman, A. M, Lewis, J., Chandrasekharappa, S. C., \& Chitnis, A. B. (2003). Mind Bomb Is a Ubiquitin Ligas That Is Essential for Efficient Activation of Notch Signaling by Delta. Developmental Cell, 4, 67-82. https://doi.org/10.1016/S1534-5807(02)00409-4

Kimpouni, V., Apani, E., \& Motom, M. (2013). Phytoecological Analysis of the Woody Flora of Upper Sangha (Republic of Congo). Adansonia, sér. 3, 35, 107-134. https://doi.org/10.5252/a2013n1a9

Kimpouni, V., Loumeto, J., \& Mizingou, J. (2008). Diversite floristique du facies forestier à Aucoumea klaineana (Okoume) du littoral Congolais. Acta Botanica Gallica, 155, 323-334. https://doi.org/10.1080/12538078.2008.10516113

Kimpouni, V., Mbou, P., Gakosso, G., \& Motom, M. (2013). Floristic Biodiversity of the Undergrowth and Natural Regeneration of the Brazzaville Goose Paw Forest, Congo. International Journal of Biological and Chemical Sciences, 7, 1255-1270. https://doi.org/10.4314/ijbcs.v7i3.31

Koualalanda, R. (2019). Diversité floristique et estimation du stock de carbone des forêts de la Reserve de Faune de la Lefini (65 p.). Département des Plateaux, République du Congo, Memoire de fin de formation, ENSAF, UMNG.

Koubouana, F. (2010). Composition flotistique et déterminisme de la répartition des forêts dans la Vallée du Niari. Ann. de l’WUMNG, 11, 22-37.

Koubouana, F., Ifo, S. A., Mayitoukou Loupet, L. B., \& Ndinga, E. (2016). Diversité floristique et dynamique de reconstitution de la forêt du Parc Zoologique sous plantations à eucalyptus à Brazzaville, Congo. International Journal of Biological and Chemical Sciences, 10, 609-619. https://doi.org/10.4314/ijbcs.v10i2.13

Koubouana, F., Ifo, S. A., Moutsamboté, J. M., \& Mondzali, R. (2016). Floristic Diversity of Forests of the Northwest Republic of the Congo. Open Journal of Forestry, 6, 386-403. https://doi.org/10.4236/ojf.2016.65031

Koubouana, F., Ifo, S. A., Moutsambote, J. M., Banzouzi, R. R. F., Akobe, A., Openga Ikama, C., Mantota, A. B., Ndzai, S., \& Mbemba, M. (2015). Structure and Flora Tree Biodiversity in Congo Basin: Case of a Secondary Tropical Forest in Southwest of Congo-Brazzaville. Research in Plan Sciences, 3, 49-60.

Laura di Feo (2011). Introction aux Systèmes d'information Géographique: Les SIG et le contrôle de la populationd'opossums de Nouvelle-Zélande (1 p.). Automne 2011.

Lewis, S., Lopez-Gonzalez, G., Sonke, B., Affum-Baffoe, K., Baker, T. R., Ojo, L. O. et al. (2009). Increasing Carbon Storage in Intact African Tropical Forests. Nature, 457, 1003-1006. https://doi.org/10.1038/nature07771

Mbété, P., Leckoundzou, A., Oko, C. S., Moukilou Goma, G. F., \& Koubouana, F. (2019). Evaluation of the Woody Potential of the 2018 Annual Cup Plate (AAC) in the Mpoukou-Ogooué Forestry Operating Unit (FEU). International Journal of Biological and Chemical Sciences, 13, 265-276. https://doi.org/10.4314/ijbcs.v13i1.22

Miabangana, E. S., \& Lubini Ayingweu, C. (2015). Analyse floristique et phytogéographique de la végétation de l'île de Loufézou à Brazzaville (République du Congo). Geo-Eco-Trop, 39, 55-66.

Mirkka, M. J., Tuomisto, H., Clark, D. B., \& Olivas, P. (2005). Effects of Mesoscale Environmental Heterogeneity and Dispersal Limitation on Floristic Variation in Rain Forest Ferns. Journal of Ecology, 94, 181-195.

https://doi.org/10.1111/j.1365-2745.2005.01071.x

Mondzali-Lenguiya, R. (2015). Floristic and Quantitative Analysis of the Forest of FMU 
Mbomo-Kellé(57 p.). End-of-Training Brief, Brazzaville: ENSAF, UNMG.

Moutsamboté, J. M. (2012). Ecological, Phytogeographic and Phytosociological Study of Northern Congo (Plateaus, Bowls, Likouala and Sangha) (632 p.). State Doctoral Thesis, Brazzaville: University of Marien Ngouabi.

NERF (2016). Niveaux des emissions de references pour les forêts de la République du Congo $(65 \mathrm{p})$.

Nkokolo, N. D. (2013). Suivi de la dynamique des jeunes tiges des essences de valeur commerciale dans les parcelles après exploitation: Cas de l'AAC3-2012 de l'UFP1, I'FMU Mokabi-Dzanga, Société Mokabi Département de la Likouala (61p.). UMNG, IDR, BZV Congo .

OFAC (2007). The Forests of the Congo Basin. Forest Status 2006 (258 p.). Luxembourg: European Union Publications Office.

Omatoko, J., Nshimba, H., Bogaert, J., Lejoly, J., Shutsha, R., Shaumba, J. P., Asimonyio, J., \& Ngbolua, K. N. (2015). Floristic and Structural Studies of Stands on Clay Soils at Pericopsis elata and Sandy in Julbernardia seretii in the UMA Plain Forest in the Democratic Republic of Congo. International Journal of Innovation and Applied Studies, 13, 452-463.

Pascal, J. P. (2003). Notes on the Structures and Dynamics of Tropical Rainforests. Description and Dynamics of Forest Environments (13 p.).

Phillips, L. O., Reitsma, J. M., White, L., Comiskey, J. A., Djuikouo, K. M. N., Ewango, C. E. N., Feldpausch, T. R., Hamilton, A. C., Gloor, M., Hart, T., Hladik, A., Lloyd, J., Lovett, J. C., Makana, J. R., Malhil, Y., Mbago, F. M., Ndangalasi, H. J., Peacock, J., Peh, K. S.-H., Sheil, D., Sunderland, T., Swaine, M. D., Taplin, J., Taylor, D., Thomas, S. C., Votere, R., \& Woll, H. (2009). Increasing Carbon Storage in Intact African Tropical Forests. Nature, 457, 1003-1006. https://doi.org/10.1038/nature07771

Ricklefs, R. E. (2006). The Unified Neutral Theory of Biodiversity: Do the Numbers Add up. Ecology, 87, 1424-1431. https://doi.org/10.1890/0012-9658(2006)87[1424:TUNTOB]2.0.CO;2

Sayre, R. (2014). La sociologie de la littérature. Histoire, problématique, synthèse critique (pp. 221-228). Paris: L’Harmattan. https://doi.org/10.3917/soart.022.0221

Svenning, J. C., Kinner, D. A., Stallard, R. F., Engelbrecht, B. M. J., \& Wright, S. J. (2004). Ecological Determinism in Plant Community Structure across a Tropical Forest Landscape. Ecology, 85, 2526-2538.

UN-REDD (2015). Réduction des emissions causées par la deforestation et de la degradation des forêts (333 p). Module d'apprentissage. Edition Automne 2015.

Verheye, W. (1972). Principles of Land Classification of Arid and Semi-Arid Region (p. 42). ITC Ghent University.

Webb, C. O., \& Peart, R. (2000). Habitat Associations of Trees and Seedlings in a Bornean Rain Fores, Dt. Journal of Ecology, 88, 464-478.

https://doi.org/10.1046/j.1365-2745.2000.00462.x

Wilson, E. O. (1988). Biodiversity(521 p). Washington: National Academy Press. 